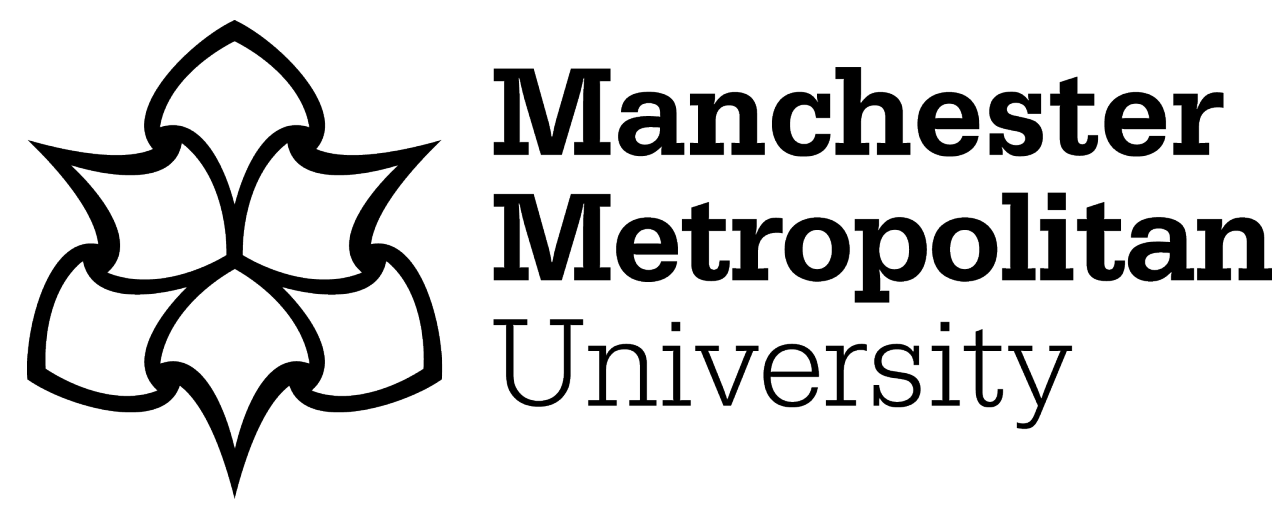

Melewar, TC and Skinner, H (2020) Territorial brand management: Beer, authenticity, and sense of place. Journal of Business Research, 116. pp. 680-689. ISSN 0148-2963

Downloaded from: https://e-space.mmu.ac.uk/621217/

Version: Accepted Version

Publisher: Elsevier

DOI: https://doi.org/10.1016/j.jbusres.2018.03.038

Please cite the published version 
Business Research

Elsevier Editorial System(tm) for Journal of

Manuscript Draft

Manuscript Number: JBR-D-17-01670R3

Title: TERRITORIAL BRAND MANAGEMENT: BEER, AUTHENTICITY, AND SENSE OF PLACE

Article Type: SI: Place Branding

Section/Category: Marketing

Keywords: Country of Origin; brand origin; terroir; authenticity; brand names

Corresponding Author: Dr. Heather Skinner, PhD

Corresponding Author's Institution: Institute of Place Management

First Author: T C Melewar, PhD

Order of Authors: T C Melewar, PhD; Heather Skinner, PhD

Manuscript Region of Origin: GREECE

Abstract: This paper explores brand management decisions concerning the terroir product of an authentic beer brand.

Findings are based on a single case study of a Greek microbrewery informed by in-depth interviews with the company owner and senior management team. Additional customer insights into the issues were gathered from 191 questionnaire responses.

Results identify the way this company has approached territorial brand management based on a clear understanding of potential consumer perceptions and reactions to clues about place brand origin in its brand names when targeting its main groups of domestic, export, and tourist consumers.

This research offers practical insights into territorial brand management decisions, especially those concerning brand names that offer clues to a product's place of origin. These insights may offer practical strategies for SMEs operating in markets serving both local and tourist consumers, and who wish to defend the terroir claims of their products against large multi-nationals. 
Cover Letter

We would like to thank the reviewers and editors. Following the acceptance decision we have received we confirm this paper has been formatted in accordance with the JBR guidelines. 


\section{*Detailed Response to Reviewers}

We would like to thank the reviewers and editors. Following the acceptance decision we have received we confirm this paper has been formatted in accordance with the JBR guidelines.

We have noted that the paper is accepted in its current form and requires no further revisions. 
TERRITORIAL BRAND MANAGEMENT:

BEER, AUTHENTICITY, AND SENSE OF PLACE

Professor TC Melewar

The Business School, Middlesex University, UK

E-mail: t.c.melewar@mdx.ac.uk

Dr Heather Skinner*

Institute of Place Management, Manchester Metropolitan University, UK

E-mail: heatherskinnercorfu@gmail.com

Telephone: +30 2661075511

*corresponding author

Dr Heather Skinner

Vraganiotika

Lefkimmi

Corfu

Greece

GR490-80

This research did not receive any specific grant from funding agencies in the public, commercial, or not-for-profit sectors. 


\title{
TERRITORIAL BRAND MANAGEMENT: \\ BEER, AUTHENTICITY, AND SENSE OF PLACE
}

\begin{abstract}
This paper explores brand management decisions concerning the terroir product of an authentic beer brand.
\end{abstract}

Findings are based on a single case study of a Greek microbrewery informed by in-depth interviews with the company owner and senior management team. Additional customer insights into the issues were gathered from 191 questionnaire responses.

Results identify the way this company has approached territorial brand management based on a clear understanding of potential consumer perceptions and reactions to clues about place brand origin in its brand names when targeting its main groups of domestic, export, and tourist consumers.

This research offers practical insights into territorial brand management decisions, especially those concerning brand names that offer clues to a product's place of origin. These insights may offer practical strategies for SMEs operating in markets serving both local and tourist consumers, and who wish to defend the terroir claims of their products against large multi-nationals.

Keywords: Country of Origin; brand origin; terroir; authenticity; brand names 


\section{TERRITORIAL BRAND MANAGEMENT: \\ BEER, AUTHENTICITY, AND SENSE OF PLACE}

\subsection{Introduction}

Contemporary consumers are seeking authenticity now more than ever (Carroll and Wheaton, 2009). This attribute of authenticity is valued so highly that consumers are often willing to pay a price premium for what they perceive to be authentic products, particularly those perceived to be authentically associated with a specific place (Moulard, Babin and Griffin, 2015). In this context, the notion of consumers increasingly 'using products and experiences to reconnect to places, history, culture, and one another' (Eades, Arbogast and Kozlowski, 2017:57), seeking to consume local products, especially in response to and rejection of the homogeneity of global consumer products, is referred to as 'neolocalism' (Flack, 1997). The concept of 'terroir', (in its simplest form, linking associations between a product and its place of production) originated within the agri-food industry. Terroir has developed strong associations with the wine industry, to which much of the extant literature on the concept now relates (Charters, Spielmann and Babin, 2017). Here authenticity can also be demonstrated through the origin of the wine producer, and also the country of wine origin, which in this case tends to lead to polarisation of 'Old' and 'New World' wines, with the former being deemed more authentic than the latter

(Moulard et al., 2015). The concept of terroir has yet to be widely accepted as a way of conveying authenticity and sense of place for beers. After water and tea, 'beer is the third most widely consumed beverage' (Patterson and Hoalst-Pullen, 2014:1). After spirits, beer is also the second most consumed type of alcoholic beverage worldwide, with almost $35 \%$ of all reported consumption, compared with only 8\% consumption of wine (World Health Organisation, 2014), 
yet there is limited consideration in the extant literature concerning beer, terroir, and sense of place compared to the plethora of such studies relating to the wine industry.

The literature has considered the way breweries attempt to create a sense of place or promoting a local identity (Carroll and Wheaton, 2009; Eades et al., 2017; Eberts, 2014; Flack, 1997; Gatrell, Reid and Steiger, 2018; Hede and Watne, 2013; O’Neill, Houtman and Aupers, 2014; Schnell and Reese, 2003; 2014). However, this previous research has tended to focus more on the what (enumerating or undertaking a content analysis of local brewery names, or local beer brand names) rather than on the why. Therefore, little is understood about why such companies make these territorial brand decisions. While Argent (2017) did undertake some qualitative research into beer brand naming made by craft brewers, his work focused more on the regional development implications of such strategies rather than on the rationale behind the brand naming decisions in any real depth.

Many past studies have investigated the extent to which a product's country of origin (COO), or product country image (PCI) exerts an effect that influences consumers' perceptions of imported products based on the stereotype image of the exporting country (see, for example, Han, 1989; Johansson, Douglas and Nonaka, 1985; Kotler and Gertner, 2002; Tse and Gorn, 1993). Suter, Borini, Floriani, da Silva and Polo (2018) have recently offered a range of examples that stress how a firm can incorporate a home country advantage by incorporating such COO into their branding, in order to leverage country-specific advantage (CSA) and transform this into a firm-specific advantage. The extant literature is also replete with associated studies that consider ethnocentric and patriotic purchasing of products from a country by consumers 
from within that country. However, a significant gap in the Country Of Origin (COO) literature has arisen because these previous studies had tended to consider $\mathrm{COO}$ in isolation from other elements that may have an effect on purchasing (Eroglu and Machleit 1989). Phau and Suntornnond (2006) identify a further gap in the literature, concerning the lack of COO research in relation to fast consuming goods, and low involvement products, as opposed for example, to studies regarding country of origin and the purchase of luxury products (Godey, Pederzoli, Aiello, Donvito, Chan, Oh, Singh, Skorobogatykh, Tsuchiya and Weitz, 2012). Whereas Phau and Suntornnond (2006) consider beer to be categorized among such low involvement fast consuming goods, Bech-Larsen, Esbjerg, Grunert, Juhl and Brunsø (2007:7) believe that food and drink can convey 'cultural meaning' and are therefore 'significant beyond their utility and conventional value'. These meanings can be particularly evidenced in the tourism literature, where consumption of local food and drink is not only seen to enhance the tourist's authentic destination experience, but is also driving food-related tourism to emerge as a growing tourism subcategory, as destinations seek to attract target market segments whose primary motivation to visit a destination is the gastronomic experience (Williams, Williams, and Omar, 2014).

Similarly to calls for much of the other place-based literature to expand its dealing with rural and regional places (Greaves and Skinner, 2010), there has also been an additional call for researchers to extend the study of $\mathrm{COO}$ into wider issues of place-based marketing, and to consider not only country of origin of a product, but also 'to more specific geographic origins such as regions, states, or river basins' Orth, McGarry, Wolf and Dodd (2005:89). One such example of where a consideration of 'regional place identities and the space of beer production' can be found is in Kalandides' (2011) description of the Prenzlauer Berg district of Berlin. This 
region had been well renowned for beer making since the nineteenth century, until by 1900 there were 21 microbreweries all located in that one place which has now become mostly residential, but which, and in no small part because of the existence of these breweries that provided 'biergartens' and hosted parties, was also a centre of entertainment even up to the 1940s.

Furthermore, recent research into the beer industry in general, and smaller craft breweries or microbreweries in particular, tends to have focused heavily on the United States (Carroll and Wheaton, 2009; Eades et al, 2017; Gatrell et al., 2018; Geppert, Dörrenbächer, Gammelgaard and Taplin, 2013; Flack, 1997; Hede and Watne; 2013; O’Neill et al., 2014; Pitta and Scherr, 2009; Schnell and Reese, 2003, 2014; Shears, 2014;) Canada (Eberts, 2014; O’Neill et al., 2014), Australia (Argent, 2017; Hede and Watne; 2013; O’Neill et al., 2014; Phau and Suntornnond, 2006), and Northern Europe (Bech-Larsen et al., 2007; Burghausen and Balmer, 2014; Geppert et al., 2013; Hede and Watne; 2013; Kalandides, 2011; Lewis and Stubbs, 1999; Nelson, 2014; O'Neill et al., 2014; Yool and Comrie, 2014). Other than Vrellas and Tsiotras' (2014) article, the brewing industry in Greece has been largely ignored, possibly due in no small part because of the lack of a history of brewing and beer consumption in this country. However, as we see more global travel, increased consumption of lager type beers across the world, and the rise of global companies distributing and promoting their brands worldwide, along with the attendant rise of the craft brewing industry, it would appear timely to examine empirically the issues of beer, sense of place, terroir, brand origin and authenticity outside of the places that have already received the majority of attention. 
This paper takes the case of a microbrewery on the small Greek island of Corfu to examine the company's territorial brand management decisions for their authentic beer brands that are imbued with a sense of place. The study will be contextualised within the origin-bound products literature and the marketing implications of terroir and neolocalism, focusing specifically on where these issues relate to the concepts of authenticity and cultural consumption. The contribution this research makes is to fill a number of recognised gaps in the literature by extending the study of $\mathrm{COO}$ into wider issues of place-based marketing, including the brand management of terroir products, and wider than 'Country' of product origin to more specific and localised geographic regions.

The overall aim of this research is to explore the brand management decisions concerning the terroir product of an authentic beer brand imbued with a sense of place, in order to establish:

- How and why the brewery established its company and beer brand architecture

- How and why the brewery named its beer product brands

- How important consumers perceive it to be to consume local food and drink products

- The importance of authenticity of country of origin to beer consumers

- The extent to which beer brand names convey a sense of place

Results identify how and why this company has approached territorial brand management based on a clear understanding of potential consumer perceptions and reactions to clues about place brand origin in its brand names when targeting its main groups of domestic, export, and tourist consumers, thus creating a beer brand consumers value and which is deemed to be imbued with an authentic sense of place. 


\subsection{The European Brewing Industry}

Across Europe, family owned organizations are the 'most prevalent type of ... ownership category' (Hautz, Mayer and Stadler, 2013:106). These types of organizations tend to be more locally connected, more focused in their strategy, committed to long-term survival of the firm, less likely to separate organizational ownership from organizational control, having both family and non-family members in managerial positions (Harris and Ogbonna, 2007). In the brewing industry where family owned firms are commonly found, such organizations are also 'adept at balancing entrepreneurship with professional management' (Geppert et al., 2013:319), something not always evidenced within family owned organizations in other industry sectors. Unlike European family-owned organizations in other industry sectors that tend to be less likely to diversify internationally (Hautz et al., 2013), brewers such as Heineken and Carlsberg only grew to their current positions of industry strength by being international from the outset (Geppert et al., 2013), although Calori, Johnson and Sarnin (1992:71) did find a great difference in size of the industry's competitive players, which tend to be polarized 'between groups which have become, or are becoming, international, and small highly focused brewers'.

Pertinent to this research is that historically, while beer has commonly produced and consumed throughout most of Europe from around $1000 \mathrm{BC}$, it was not commonly found in either Southern Italy or in Greece (Nelson, 2014). Thus, because Greece does not have a long brewing history it is perceived less as a country of beer origin than many other European nations.

While 'beer was previously a very local product', nowadays 'approximately half of global sales [is] controlled by just four firms: AB InBev, SABMiller, Heineken, and Carlsberg', each of 
which has their headquarters in Western Europe (Howard, 2014:155). In Greece, 90\% of the beer market is dominated by two of these global companies. The largest of these, with around $75 \%$ market share is the Athenian Brewery, 'a member of the Netherlands' HeinekenNV, the third largest brewer worldwide'. The Athenian Brewery produces the Amstel, Heineken and Alfa beer brands that are found widely across Greece and the Greek islands. The Mythos Brewery holds around $15 \%$ of the Greek beer market, and 'is a subsidiary of Denmark's Carlsberg Group, the world's fourth-leading brewer' (Vrellas and Tsiotras, 2014:31). The Mythos Brewery produces the Mythos brand, which is available to purchase in 30 countries and 'which has a loyal - some would say fanatical - following' (Vrellas and Tsiotras, 2014:36).

Despite the dominance in this market of these two corporations and their four main product brands, in their 'Overview of the Greek Brewing Industry', Vrellas and Tsiotras do note the recent appearance of Greek microbreweries. 'A microbrewery produces a limited amount of product per year. Usually the benchmark maximum amount of beer one can produce is around 15,000 barrels annually' (Pitta and Scherr, 2009:153). If that microbrewery is also attached to a retail outlet, it remains categorized as a microbrewery as long as it sells no more than $25 \%$ of its production onsite. The classification 'brewpub' then tends to apply to a microbrewery that sells more than this amount onsite. The recent literature has also seen the increasing use of the term 'craft brewery'. The distinction between microbrewery and craft brewery is often one of size, especially when the term 'craft brewery' is used to distinguish its production from the 'craft beers' produced by large brewing companies. However, similar to Schnell and Reese (2003; 2014) in the context of this research such definitional distinctions between microbrewery and craft brewery are not of particular relevance. Corfu Beer is a microbrewery that brews craft 
beers, and while consumers may sample beers on the brewery tour and may also purchase bottles to take away, there is no onsite pub or restaurant. Similar to other real ale producers which form the basis of the traditional brewing industry, Corfu Beer occasionally produces special seasonal beers (Pitta and Scherr, 2009).

As the larger brewing companies have tended to grow through mergers, and through acquisitions of smaller local breweries, typically they are also therefore able to adopt strategies using 'a dual approach to market a small number of global brands, as well as a diversity of local brands tailored to specific markets' (Howard, 2014:163). Therefore, even when individual national or local beer product brands remain in production, and notwithstanding the prevalence of small family-run breweries, many 'local' beer brands are often now in the ownership of these large global corporations. This mode of market entry, where a smaller brand is now owned by a larger multi-national, and also the mode of market entry utilizing a cross-border strategic alliance between a larger multinational and smaller home organization can be a highly effective way of managing consumers perceptions of a product brand's country of origin (Lee, Lee and Lee, 2013).

\subsection{Country Of Origin, Authenticity, and Terroir}

One of the ways a company may choose to offer clues as to the country of origin of its products through a brand name. However, not all such origin claims are authentic. Some products are deliberately named to give a sense of brand provenance that simply does not exist. For example, Simms (2008) describes many cases where brands deliberately fake their nationality through their product name in a deliberate attempt to persuade consumers that a 
product is associated with a particular place, and notes this is particularly prevalent in the beer industry, although there are many other examples. The issue is further clouded by today's global market where COO may mean, variously, the country of manufacture or production, the country of assembly, or the country in which the company owning the product brands is located. The Mythos and Alfa products have Greek sounding names, both are brewed in Greece by breweries with Greek sounding names (Mythos by the Mythos brewery, Alfa by the Athenian Brewery), but are also both owned by large multinational companies headquartered respectively in Denmark and the Netherlands. In an attempt to clarify such matters, Thakor and Lavack (2003:403) distinguish between 'the country where the brand is owned' (brand origin) and 'the country where the product's parts are made or where the product is assembled' (COO). Zhou, Yang and Hui (2010:203) believe that the concept of Confidence in Brand Origin identification $(\mathrm{CBO})$ can be a moderating factor on Perceived Brand Foreignness (PBF), a concept that is especially relevant 'in a marketplace filled with uncertainty about actual brand origins due to the imitation strategies of local rivals and/or the localization movement of international players'.

However, the management of the $\mathrm{COO}$ effect rests on the ability to demonstrate a positive association between 'product-country match' or 'product ethnicity' (Moulard et al., 2015:64). For example, some wines are perceived as better than others because their region of origin is perceived as being more favourable compared with other regions even in the same county, and especially when that country is also perceived as favourable for wine production. Thus, it becomes relevant for wine producers in these more favourable regions to be able to protect and communicate their association with the region, and it is usual to adopt such practices as certifying a wine's region of origin on its label (Josias, Frikkie and Johan, 2014). Producers of 
other products similarly label these to display a certification of origin (Charters et al., 2017). Where local food and drink products have been granted special protection from the European Commission for their local status, such protection is designed to 'protect product names from misuse and imitation and help consumers by giving them information concerning the specific character of the products' (European Commission, 2016). There are three different such protection schemes offered by the European Commission:

- Protected Designation of Origin (PDO) - 'covers agricultural products and foodstuffs which are produced, processed and prepared in a given geographical area using recognised know-how'

- Protected Geographical Indication (PGI) - 'covers agricultural products and foodstuffs closely linked to the geographical area. At least one of the stages of production, processing or preparation takes place in the area'

- Traditional Speciality Guaranteed (TSG) - 'highlights traditional character, either in the composition or means of production' (European Commission, 2016).

The European Commission's Database Of Origin and Registration (DOOR) shows that of the 1,388 registered products across the EU, across Greece there are only 104 registered protected products with one further product within the PDO application stage (European Commission, 2017). These protection schemes usually require that the product's content itself comes from a specific place, and also that the link between the place and the product's raw materials are unique to that place (Charters et al., 2017). So, for example, Santorini Fava (yellow split peas) have been granted PDO status. While fava is a dish that is widely available across Greece, it is famous to the island of Santorini, and it is the yellow split peas only from Santorini that are 
offered this protected status. Such authentic 'ingredient branding' is also seen to be a driver for consumers purchasing luxury clothing brands and can also be used by producers 'in order to justify low country image perceptions as trade-offs for high quality raw materials or expert artisan techniques' (Cheah, Zainol and Phau, 2016:5829). In the case of this research the concept of such technical terroir relating to a product ingredients' 'location specificity' (Moulard et al., 2015:75) is of less relevance because this paper considers not necessarily product types that are already associated favourably with a region or country, but rather, how a company can position a product as being authentic because of the very nature of the place of origin of both the product and the company, and how such authenticity can be communicated through its product brands, even when no real association between the product type and its place of origin exists. Moreover, while Suter et al., present the theoretical argument of how a company may utilize a country specific advantage into their branding, our paper presents a real-world example of how one company (Corfu Beer) has managed to leverage its beer production, for which Greece does not have a strong image as a country of origin, and translate this into a strong firm-specific advantage.

Empirical research has shown that because beer is relatively ubiquitous, a beer brand does not have to be perceived as unique or individual to be perceived as authentic (Schallehn, Burmann and Riley, 2014). A study into the COO knowledge of beer brands with Australian consumers found that 'the foreign brands available in the market such as Heineken and Beck's can make use of their country of origin images by emphasizing their superiority in product quality and social acceptability' (Phau and Suntornnond, 2006:39) over more local beers. Thus suggesting that, in some cases, the PBF identified by Zhou et al., (2010) can be perceived as a positive rather than 
negative product attribute. In their research into certain regional food and beverage brands from the North East of England, Lewis and Stubbs (1999:376) found that one brand, Tetley's bitter beer brand, had strong connotations to the Yorkshire region, 'but although these were viewed very positively within Yorkshire they were a two-edged sword outside the county'. 'It appears therefore that the issue of its region being the "natural home" of a product could be an important advantage to a brand, as long as there are no negative characteristics' (Lewis and Stubbs, 1999:380).

\subsection{Summary}

In summary, the European beer brewing industry is polarized between at one end of the spectrum small, often family-owned, businesses who can exhibit strong entrepreneurial and professional business management skills compared with other such firms in different industries, and at the other end, large multinationals that tend to dominate market share. Some beer product brand names may be perceived as local to a particular area because historically they indeed were owned and produced in that area, even though they may since have become under the ownership of a larger multinational company. Some may be deliberately named to create a fake brand provenance and associations with a particular place, while others may be perceived as being authentic in relation to both country of brand origin and country of company ownership. Certain certification schemes are in place that may help a local brand protect its authenticity claims, thereby increasing consumer confidence in brand origin. Yet while associations with a country of origin and the product types it produces is mostly used to increase favourable perceptions of a brand, in some cases, the very fact that a product is foreign can be perceived by consumers as a more positive attribute than if a product is authentically local. However, food and drink products 
can convey cultural meaning, and so authenticity becomes of particular concern both for tourists, and for other contemporary consumers for whom authenticity is becoming increasingly important.

To take a broader consideration of the conceptualization of terroir than making a more simplistic geographical link between agri-food ingredients and place thus requires the inclusion of a focus on 'the more metaphysical concept of spatial and cultural meaning, and the role of human enterprise' (Charters et al., 2017:12). All these elements, together with the more precise geographical / topographical / environmental characteristics more usually identified with the concept of terroir can 'differentiate value propositions' (Ibid. p12) and allow 'producers and firms [to] gain competitive advantage from promoting the authenticity and added-value of their terroir products' (Ibid. p2). This research therefore furthers the application of this concept by filling a gap in the literature recognised by Charters et al., (2017:27) for future research to consider 'the relationship of terroir to effective territorial brand management' and the way the brand's manager manages this with regard to 'product development and improvement'.

These issues will now be explored in light of the territorial brand management decisions of the family-run microbrewery chosen to provide the case material for this study, located in Corfu, a small Greek island heavily reliant upon tourism in the summer, but also serving local and geographically near export markets to extend throughout the year their sales of a seasonal product with a short shelf life. Links can therefore be drawn between the focus of this study and with many rural destinations that need to serve both tourists' and local residents' needs, in order 
to 'overcome obstacles of remoteness and seasonality' and to 'sustain economic growth (Hurst and Niehm, 2012:195).

\subsection{Methodology}

This research is based upon the study of a single case. A case study approach is appropriate when there is a lack of available previous data on a certain subject, when considering the rationale behind marketing decisions, and has also been used by others to study the marketing decisions of breweries (Lewis and Stubbs, 1999). Geppert et al., (2013) similarly undertook case study research into management decisions in the brewery industry but did use multiple cases. Burghausen and Balmer (2014) undertook single case research into the Shepheard Neame brewery, a single case method was also employed by Newey and Zahra (2009) when examining product portfolio planning and entrepreneurship. In further defense of the single case approach, Buchanan (1999:S77), while noting the criticisms levied against single cases regarding the lack of external validity, believes that generalization may be found from the results of single case studies, if the case explores 'implications for current theory and conceptualizations of the issues explored' thus, 'the task of the researcher is thus to choose an appropriate case (or cases), to seek patterns, to develop assertions, to anticipate generalizations in a provisional manner, to link conclusions to current theory'.

Similar to Burghausen and Balmer's (2014) single brewery case study, data were also gathered for this study from company documents, including research reports and promotional 
material, and gathered visual data from photographs taken by the researchers during site visits, informing our study 'in a secondary fashion in order to enrich and corroborate insights derived from interviews and document research'.

In the initial stage of this research primary data were gathered from in-depth interviews with the microbrewery's owner $(\mathrm{O})$ and senior management team - Marketing Manager (MM), Sales Manager (SM), Financial Director (FD), and Communications Manager (CM). All interviews were conducted on the brewery's premises. Each interview lasted approximately 60 minutes. Interviews were tape recorded and transcribed. The first language of all interviewees is Greek. Despite the offer of having interview guidelines translated in advance, and the offer of a translator to be present, all interviewees chose to be interviewed in English by the researchers. In the interview with the brewery owner, a translator was present who was able to clarify certain concepts raised during the interview on occasion, as and when required.

The interviews with the brewery's owner and management team were guided by an understanding of the concept of Corporate Identity (CI), as this is what makes an organization unique, and incorporates everything about the organization's communication, design, culture, behaviour, structure, industry and strategy. For the purposes of this research, the CI construct appeared to be pertinent to addressing the overall aim of this research exploring the brand management decisions of the terroir product of a local beer imbued with an authentic sense of place. Thus the interview protocol we followed included questions specifically relating to the seven dimensions of CI identified by Melewar and Karaosmanoglu (2006), namely: Corporate Communication (encompassing controlled, uncontrolled and indirect communication); Corporate 
Design (encompassing the corporate visual identity system and its application); Corporate Culture (encompassing the corporate philosophy, values, mission, principles, guidelines, history, along with the founder, country of origin, and subcultures of the corporation); Behaviour (corporate, employee and management); Corporate Structure (encompassing the brand and organizational structure); Industry Identity; and Corporate Strategy (examining both differentiation and positioning strategy). This allowed the researchers to gain deep insights into the way this company has approached territorial brand management, specifically regarding:

- How and why the brewery established its company and beer brand architecture

- How and why the brewery named its beer product brands

The interviews were also designed to draw out management insights into potential consumer perceptions and reactions to clues about place brand origin in its brand names when targeting its main groups of domestic, export, and tourist consumers. Thus evidencing the way the company's CI is not only created, but also communicated. Coding of the interview transcripts was undertaken manually and results confirmed between the two researchers.

Stage 2 of the research complemented the findings from the management side with a consumer study in the form of an online survey. Mixed methods research has become increasingly popular in the social sciences. Depending on the aim of the research it is not always considered necessary to undertake random sampling in order to achieve generalisable results, and indeed when undertaking case research it is considered appropriate to select a sample 'based on specific characteristic(s) because their inclusion provides the researcher with compelling insight about a phenomenon of interest' (Onwuegbuzie and Collins, 2007:285-286). While a sample of 
191 respondents may be considered relatively small in size, Onwuegbuzie and Collins (2007) also stress not only that small sample sizes may be appropriate when undertaking exploratory research, but also that descriptive analysis may also be appropriate in mixed methods research.

A link to an online survey was sent out via social media targeting beer consumers who live or holiday on Corfu. The link was sent out to place specific Facebook groups (for example, closed groups such as 'Arillas Addicts', 'Fans of Messonghi', and 'Corfu Islanders') where, as far as possible, it ensured only those with links to places on Corfu as either tourists or residents (Greek and ex-patriates) would receive the link and access the survey. It was made clear that only those who consumed beer when on Corfu should answer the questionnaire. The initial question asked respondents to identify from Mythos, Alfa, and Corfu Beer, which they preferred to drink.

Results of the survey were analysed for the responses as a whole, and then by the variable of beer brand preference for questions concerning:

- How important consumers perceive it to be to consume local food and drink products

○ Guided by Flack's (1997) understanding of the rise in 'neolocalism' and consumer's preferences for local products, particularly for tourists who may choose to consume authentic beer products that relate to the location they are visiting (Eades et al., 2017; Eberts, 2014).

- The importance of authenticity of country of origin to beer consumers

○ Guided by Carroll and Wheaton's (2009) belief that contemporary consumers are increasingly seeking authentic consumption experiences.

- The extent to which beer brand names convey a sense of place. 
- Guided not only by the understanding that many producers choose to name brands to provide a sense of place (Eades et al., 2017; Suter et al., 2018), whether that place association is authentic or not (O’Neill et al., 2014, Simms, 2008) but also to gain insights into the way such names are perceived as doing so by consumers.

Analysis of the findings from both the qualitative management interviews and quantitative consumer survey will be presented under each research objective and then summarised as to how the overall aim of the study has been met.

\subsection{Results}

\subsection{Establishment of the company}

The Corfu Beer company was first established in 2006, but the owners were unable to access the funds required to set up the brewery factory due to the economic crisis, so the business proper was started only in 2008, with the first beer produced in 2009. Corfu Beer is the largest of all the microbreweries in Greece. Similar to many other European breweries, the company is family owned and managed (Hautz et al., 2013). The owner also believed it to be important to establish the brewery in his home village of Arillas, a small village in the North West of the island, around an hour-long drive across a mountain range away from Corfu Town. Thus the company is also more connected to its location than larger breweries may be (Harris and Ogbonna, 2007).

The brewery has established 2 legal entities: Corfu Microbrewery Ltd and Corfu Beer Ltd. When the company name is written in English it always appears as 'Corfu Beer'. When written in Greek the company name that is used translates as 'Corfu Microbrewery', whereas 'Corfu 
Beer' is also one of the product lines the company produces. The company logo is in the form of

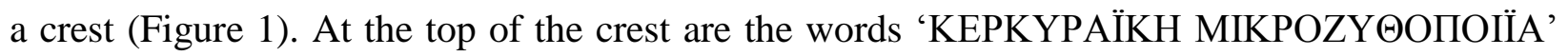
('Corfu Microbrewery' in the Modern Greek orthography). Under these words is a crown of 5 ears of grain. Within the crest is the outline of Corfu, sharing space with the letters ' $\mathrm{CB}$ ', Corfu Beer - words that appear in English below the crest, just under the MMVI inscription for 2006, the date the company was formed. On each side of the crest is a lion, a symbol that not only identifies with Corfu's years under Venetian rule, but also to the astrological star sign (Leo) of the company owner. "On our logo the two lions protect the island ... the lions in Corfu you can see everywhere lions, and it's in our minds. " [MM]

\section{Figure 1 - Corfu Beer logo}

It was the dominance of Heineken and Carlsberg's brands in the Greek market that inspired the microbrewery's owner to start the company. On an island whose beer market is at its peak during the summer tourist season, he recognized that there was a lack of an authentic local Greek beer product available. Moreover, the lack of an authentically local beer brand available to local residents also does not contribute much to the island's economy outside of the tourist season. The owner also believes that establishing strong local microbreweries is the only way forward for this region to compete with the two large global players who continue to dominate the market.

"Only the small breweries can be the future, the answer of the market is the very small business, is like the Hydra, cut one head off and rises another ... The beer is a brand everywhere, in every city, in every village everywhere you want to drink their beer and 
we want to do the same here, and I hope in the future all the islands will have small microbreweries to give quality products, it would be nice". [O]

\subsection{Establishment of the company's beer brand architecture}

The company produces a Dark Ale Bitter, Real Ale Special, Contessa IPA and the Amorosa Weiss under it's 'Corfu Beer' brand range. Under its 'Ionian' brand range are the Royal Ionian Pilsner (available in bottles), Ionian Gold (a 4.2\% keg Pilsner), Ionian Epos (with barley malt and honey), and a Royal Ionian Ginger Ale. The company also produces the 1842 brand, a lowalcohol brewed ginger beer flavoured with lemon. However, like many other microbreweries, the Corfu Beer company has also produced occasional one-off beers for special events. Its Coffee Porter, under its Ionian product line, was a one-off special beer sold in the UK through the pub chain Wetherspoon as part of its 2013 Spring Festival. The special 'Weissbier' produced for the company's own 'Corfu meets Bavaria' week-long beer festival held in Arillas in October 2013 is now available as the Amorosa and is retained under its Corfu Beer product line.

\subsection{Territorial brand management decisions: positioning, pricing, brand naming, and visual} identity

The company's aim was to create truly authentic local beers with a local Corfiot character, offering a natural, fresh, living beer product to the market targeted at three segments: Tourists; local inhabitants; and to geographically close export markets. Not only would this contribute to the product's differentiation against those of the mass brewers, but it also aligns with the owner's personal philosophy of offering a product made with no preservatives, no chemicals, and, where possible, using local ingredients (for example, the lemons used to flavor the 1842 ginger beer). 
Authenticity often comes at a price, yet consumers who value authenticity in the products they purchase seem willing to pay a price premium for this valuable attribute (Moulard et al., 2015). Price sensitive consumers may prefer to purchase these global mass-produced brands more than a local, more expensive, bottled real ale. However, the company pays close attention to price perceptions and value for money, and its keg pilsner is priced comparably to the Mythos brand. For those local or tourist consumers for whom brand origin is important, and for whom consuming such a cultural product as local beer is important to convey a sense of place (BechLarsen et al., 2007), COO can be seen to work with, rather than in isolation from, other elements such as pricing that may have an effect on their decision making (Eroglu and Machleit, 1989). Corfu Beer is not aimed at being a cheap brand, but it is not highly expensive either, although the bottled beers are generally slightly more expensive than the market leader brands Amstel, Heineken, Mythos and Alfa: “our lager it's the same price, maybe cheaper than Mythos, on draft" [FD]. Consumer research that the company undertook in Athens showed that its pricing strategy is deemed very fair and offers good value for money. The owner is also concerned not to set his prices too high for local people, especially as he understands the problems facing an island in the current economic climate, where many local people are also relying on seasonal tourism employment for their annual income: "in our local market, local beer for Corfu must be a reasonable price for local people” [O].

Corfu Beer has produced the occasional seasonal product for special events. However, unlike many other real ale brewers for whom seasonality is more often addressed by producing such 'seasonal' beers (Pitta and Scherr, 2009), Corfu Beer decided to address seasonality through 
exporting. The reason in this case may be found less in industry sector, and more in in the geographical location of Corfu as an island tourism destination whose economy is still heavily reliant on an increasingly shortening summer season (Skinner, 2015). Therefore, many businesses seek to address issues of managing supply and demand that peaks considerably in the high season summer months and decreases equally dramatically in the long winter months. Thus these businesses must find solutions that serve and build relationships both with tourists in high season and local consumers all year round (Hurst and Niehm, 2012). The company does not export far. It serves only major cities on the mainland of Greece (Athens and Thessalonika), and exports also to the other of the seven Ionian Islands (including Paxos, Lefkada / Lefkas, Ithaca, Kefalonia, Zakynthos / Zante and Cythera) under whose Prefecture Corfu falls. The decision to venture into only these geographically close export markets was taken because the company produces only natural beers with no chemicals or preservatives that therefore have a shelf life of no more than around two months:

"we brew fresh beer, we have fresh beer, this fresh beer we can't brew in the winter to sell it in the summer... we must to find market in the winter, and the market in the winter is in Athens and Thessalonika” [O]

The company regularly receives requests from tourists for details of where its products can be found in other countries, but further growth through wider exporting, licensing or franchising has been discounted for the time-being. The company is still very small, does not want to overextend itself at the risk of losing product quality and brand reputation, is still not achieving full production capacity for its current markets, does not currently have the staff to potentially 
manage a licensing or franchise arrangement in foreign markets, and wishes to remain authentically local to Corfu in terms of ownership and production of its brands.

There is a clear distinction between the way the company and its product brands are named when presented to tourists compared with its local markets in Corfu and its near export markets. The Corfu Beer brand is most widely sold on the island itself and in its mainland markets. The Ionian beers are available in Corfu and also more widely across the other Ionian Islands. The territorial brand naming decisions made by this company, based on an understanding of customer relations with potential stockists on the other Ionian Islands, to produce an 'Ionian' brand, bear out earlier research by Lewis and Stubbs (1999) into beer brands that are imbued with a sense of place due to their brand name. 'Corfu' has positive connotations on the island itself, and also on the mainland of Greece, but stockists on the other Ionian Islands would be less favorable to a 'Corfu Beer'. Therefore, the decision to produce an 'Ionian' brand for these markets would seem to be an effective strategy.

Each of the company's main brands has been carefully named to reflect a sense of place. For example, the inspiration for the Ionian Epos came from Homer: "you know Homer say that when Odysseus comes to the islands he drinks barley wine ... in the barley wine, we use honey to make more alcohol ... We make Ionian Epos, we say 3000 years after Homer we try to again brew some in Greece". Thus, although Greece is not generally associated with beer brewing, the company found a link through the well-known mythological stories of the author Homer. In this case, Corfu is widely regarded as being 'Scheria, the land of the Phaeacians where Odysseus was shipwrecked and recounted his adventures' (Hopkins, 1977:22-23). Thus the company has made 
a connection between these stories, beer, and the place in which they are located. The 1842 ginger beer is so named because that was the year in which a brewery was established on the island to brew ginger beer for British soldiers at a time when Corfu was a British Protectorate: "we ... belonged to the British for nearly 50 years between 1814 and 1864, 50 years, so we have the British culture in many different things" [O].

The company's territorial brand management decisions have also extended to its visual identity, in terms of company logo and bottle labelling that give it a distinctive identity in the market. The company logo appears on the side of the delivery vans, its bottled beer products, and on all the company's merchandising, including T-shirts, coasters, beer glasses, banners, and on all stationery and promotional literature. Indeed, the company's logo is so identified with the company's products by its tourist market, that many beer glasses are stolen from bars as souvenirs. While O'Connor (2014) believes that distinctive design can be difficult to achieve with regard to beer bottles, this can be seen as a form of visual clue to brand ownership, and forms part of its territorial brand management, all of which is designed to closely associate the company and its products with its locale of both ownership and production. The design on the bottle of the 1842 ginger beer conveys a sense of place as well as a sense of the product, using blue and yellow - the colors of the Ionian Sea and the lemon ingredient. When discussing how he worked with the graphic designer of the bottle's labelling the owner said that: "I have some photographs of the Ionian sea ... and I say, take this photo and make it to feel like there is a gas, gas inside it" $[\mathrm{O}]$

\subsection{The extent to which beer brand names convey a sense of place}


The consumer survey respondents were asked to rate each of the beer brands Mythos, Alfa, and Corfu Beer they preferred to drink on a scale between 1 (extremely low preference) and 5 (extremely high preference). Table 1 shows that $69.47 \%$ of respondents rated Mythos towards the higher end of the scale (rating as 4 or 5), slightly above those who rated their high preference for Corfu Beer (66.12\%). In contrast, Alfa was rated 1 or 2 (towards the lower preference end of the scale) by $30.9 \%$ of respondents, with only $36.52 \%$ of respondents rating it 4 or 5 towards the extremely high preference end of the scale and similarly $32.58 \%$ rating this beer at the mid-point. Table 1: Beer brand preferences

Overall, $72.25 \%$ of survey respondents $(n=138)$ believe that a beer's brand name helps them know which country it is from. Naming beers such as Mythos and Alfa make consumers perceive them to be authentically Greek, even though the brands are now owned by large multinationals. Table 2 shows the percentage of respondents overall who believe that based on the name alone these brands are 'authentically' Greek, with 1 being the rating for the beer brand deemed to be least authentically Greek and 5 being the most authentically Greek. Corfu Beer is deemed to be the most authentically Greek (according to those who rated each beer name's authenticity as 4 or 5) by $76.51 \%$, followed by $62.91 \%$ who similarly rated the authenticity based on the name Mythos. Once again, Alfa did not rate as highly, with $31.08 \%$ of respondents rating is as the least authentically Greek (rated as 1 or 2), 32.43\% rating it mid-point on the scale, and only $36.49 \%$ rating this beer brand name as most authentically Greek.

\section{Table 2: Perceptions of authenticity}

While some tourists may prefer to drink globally recognized beer brands such as Heineken or Carlsberg, those who seek authentic 'local' beers may be motivated to purchase Mythos and Alfa 
brands because these brand names portray a Greek brand provenance, not realizing that these are also the products of these large global organizations. This is recognized by Corfu Beer's management team: "Mythos is not Greek, Alfa is not Greek, but they sell like they are Greek" [FD]. Each of the company's beer brands have been named with a lot of thought as to how they will be perceived in the marketplace. There is a strong rationale for having both the Corfu and Ionian brand names. The Ionian range has been so named in order to appeal to the company's near export markets across the other Ionian islands, where the company understands that a "Corfu" beer may not be as widely accepted.

“In Corfu, many shops sell only Corfu Beer” [CM]

"if you go in Kefalonia and you say is just Corfu Beer, they say, OK I want to sell

Kefalonia beer" [SM]

“Nobody will take 'Corfu' in Kefalonia ... for this I want to see 2 brands. Ionian I want

To be the beer of the Ionian Islands one day ... already we sell some in Kefalonia, some in Lefkada ... to sell 'Corfu Beer' is impossible” [O]

Authenticity is a concept that has driven all of the company's territorial brand management decisions. As it is a relatively newly established company, Corfu Beer was able to make all their branding decisions based on a clear understanding of the customers across the geographical region within which it operates and was able to do so without being hampered by historic decisions affecting the brand portfolio (Rajagopal and Sanchez, 2004). Whether any new beer products fall under the 'Corfu Beer' or 'Ionian' brands in the future will be dependent on which target market the beers are designed to serve. 


\subsection{Authenticity and consumption of local products}

The owner is driven not only for his company to be successful but also for this success to inspire other local producers and local businesses on the island "to have more local products, to make stronger the local brand ... to have a Corfu brand" [O]. It is therefore relatively easy to explain the decision behind establishing a Corfu Beer brand when targeting tourist consumers. The owner questions why anyone would want to come to Corfu: "to have a Heineken, McDonalds, Coca-Cola ... If you see Heineken you say, what did you have in Greece?" [O]. "Corfu Beer is Corfu beer, so I've been in Corfu and I drink Corfu Beer" [SM]. The entire senior management team also evidence a sense of local pride: "we are the local product that presents Corfu and we feel very proud of it, and we want the people that come here to ... love our product like how we love it" [CM].

\subsection{The importance of authenticity of country of origin to beer consumers}

When considering Thakor and Lavack's (2003) distinction between brand origin as country of ownership, and $\mathrm{COO}$ as where the product is actually made, this microbrewery can be seen to be authentically Greek, Ionian or Corfiot, depending on whether a country or regional approach is taken (Orth et al., 2005). The 'Corfu Beer' brand stakes as authentic a claim to both its brand origin and $\mathrm{COO}$ as does the 'Ionian' brand, and these claims can be seen to be authentically 'Greek' in all of its current markets, which are also located either on the Greek mainland or on the Ionian islands. The Athenian Brewery and Mythos Brewery, owned respectively by corporations based in the Netherlands and Denmark, could be seen to be Dutch and Danish brands, rather than Greek. Indeed, although the Athenian Brewery produce the Amstel and Heineken brands for the Greek market, these are both perceived as Dutch brands, whereas, based 
upon their brand names, the Athenian Brewery's Alfa brand, and the Mythos Brewery's Mythos brand are perceived as Greek. As these companies hold $90 \%$ of the Greek beer market share it is evident that tourists continue to purchase these brands, although some may be purchasing the Greek named beers in the belief they are purchasing an authentic local product. With the Mythos brand available to purchase in 30 countries (Vrellas and Tsiotras, 2014), this allows tourists the opportunity to consume the product at home and help them re-create their vacation experience. However, when considering Zhou et al.'s (2010) concepts of Confidence in Brand Origin identification, consumers who have knowledge of the country of ownership of these brands may well start to perceive these brands as more 'foreign' than those of this microbrewery that can authentically claim a Greek brand origin as well as COO. This will be of particular concern to those seeking an authenticity (Moulard et al., 2015), especially tourists seeking an authentic vacation experience where cultural consumption of authentic local food and drink products is seen as a significant contributor to the overall destination experience (Williams et al., 2014).

While the owner of the microbrewery is keen to create and develop an authentic Corfiot product, and keenly encourages other small local producers to do the same, there is currently no certification scheme covering products that are produced in Corfu or the Ionian region such as those found elsewhere (Charters et al., 2017). European protection schemes that rely on technical terroir (Moulard et al., 2015) may not help provide the protection of authenticity claims for a ubiquitous product such as beer. On the one hand, this may work in favour of a product such as beer that does not have to be seen to use only locally sourced ingredients or even be perceived as unique in order to be perceived as authentic (Schallehn et al., 2014). In this respect, being authentically owned and locally produced would seem to be enough, added to the authenticity of 
the natural real ale brewing methods associated with the production of authentic traditional craft beers (Pitta and Scherr, 2009) compared with those that are mass produced and which require certain chemical ingredients in order to extend their shelf life. On the other hand, effective territorial brand management of a truly authentic product can help counter the effect of fake brand provenance claims being made, especially in the beer market that is not only very crowded, but where such fake claims are commonplace (Simms, 2008).

When asked how important it was when in Corfu to consume local food and drink, $87.96 \%$ $(n=168)$ of survey respondents answered that it was extremely important to them, $10.47 \%(n=20)$ that it was of some importance, and only $1.57 \%(n=3)$ that it was either of little or no importance. However, the issue of authenticity and consumption of 'local' products is clouded when seemingly 'local' brands are now owned by large global companies. Overall responses were fairly similar concerning whether it did matter to the drinker if a 'Greek' beer was owned by a global company such as Heineken or Carlsberg $(50.79 \%, \mathrm{n}=97)$ or whether the brand's ownership in this respect did not matter to them $(49.21 \%, \mathrm{n}=94)$. The most interesting results come from considering responses to these issues based on the beer drinking preferences of the respondents. Table 3 shows the responses to issues of name authenticity and importance of local consumption based on the consumer's preferred beers (having rated each as 4 or 5 on the scale of extremely low to extremely high preference).

\section{Table 3: Beer preference, brand names and local consumption}

Overall there was little difference between the responses of those who prefer to drink Mythos, Alfa, or Corfu Beer about how important they each believed it was for them to consume local products when in Corfu, with consumers stating overwhelmingly (over $98 \%$ of respondents) that 
it was indeed of extreme or of some importance to them. Responses were also similar across the different consumers who preferred to drink each beer about a beer brand name conveying its country of origin. However, while these responses were similar across the groups, the percentages were lower, at between $72 \%$ and $75 \%$, within each group of respondents. More differences were found when considering whether or not it mattered to respondents if a beer was brewed by a Greek company that was owned by a global company such as Heineken or Carlsberg. Whereas over half of all respondents who preferred to drink Alfa or Corfu Beer did think it matters, over half of those who prefer Mythos did not. This may be explained by the loyal attachments many consumers have to this particular brand, and that it is also widely available in export markets (Vrellas and Tsiotras, 2014), thus allowing tourists the opportunity to recreate their holiday experiences while at home.

\subsection{Conclusion}

This paper aimed to explore the territorial brand management decisions made by a microbrewery in the context of the terroir product of an authentic beer brand imbued with a sense of place in order to convey a place brand origin. One common way for breweries to establish and promote a sense of local identity is through the naming of their beer brands (Carroll and Wheaton, 2009; Eades et al., 2017; Ebertds, 2014; Flack, 1997; Gatrell et al., 2018; Hede and Watne, 2013; O’Neill et al, 2014; Schnell and Reese, 2003; 2014). This study has gone into more depth than others in the extant literature concerning the reasons behind the brand management decisions regarding naming the products. Results identify not only how, but also why this company has approached territorial brand management based on a clear understanding of potential consumer perceptions and reactions to clues about place brand origin in its brand names 
when targeting its main groups of domestic, export, and tourist consumers, thus creating a beer brand consumers value and which is deemed to be imbued with an authentic sense of place.

The owner of the Corfu Beer company grew up in the local village within which he established his brewery. His family have lived in this village for generations. He and his senior management team feel a great pride not only in their company and in their products, but also in what these local products are doing for the village, the island and the wider Ionian Island region. Because of this closeness to their most local market in Corfu, and because of their understanding of the regional market across the Ionian Islands, the brewery's owner and senior management team also understood what meanings could be conveyed through not only their brands names, but also the narratives with which certain of their products are associated, particularly the 1842 ginger beer, and Ionian Epos beer. The results also bear out the notion that consumers do indeed seek authenticity (Carroll and Wheaton, 2009) through the consumption of local products associated with specific places (Eades et al., 2017; Flack, 1997; Moulard et al., 2015). In tourism markets this is particularly important for visitors who seek authentic destination experiences (Williams et al., 2014).

Corfu Beer was established as a direct challenger to the global brand such as Mythos and Alfa that appear to be authentically Greek based on their name alone, but which are owned respectively by Carlsberg and Heineken. These global giants are two of the four breweries that control almost half of all global beer sales (Howard, 2014) and 90\% of the beer market in Greece (Vrellas and Tsiotras, 2014). The beer brands Mythos and Alfa can appear to be authentically Greek due to their names alone. This allows such large global companies to position such brands 
as 'local' products (Howard, 2014; Lee et al., 2013). However, these brands are also both brewed in Greece in breweries with Greek sounding names (Mythos by the Mythos brewery, Alfa by the Athenian Brewery). Thus the concept of country of brand origin (i.e. the country where the brand's ownership is based, in these cases Denmark and the Netherlands) has also been shown in this research not to matter as much to consumers as the country of origin of production (Thakor and Lavack, 2003). Neither of these global brands are perceived to be foreign (Zhou et al., 2010), as the majority of consumers perceived them to be authentically Greek.

The concept of terroir may be more easily applied to wines where production has been historically linked to place, and where protection of such place-based associations is often gained through certification and communicated via a bottle's label (Josias et al., 2014). In general, Greece does not have a large number of products protected through various European certifications such as PDO, PGI or TSG. Greek products comprise less than $8 \%$ of all products registered by the European Commission. Because beer production in Greece does not rely on locally grown ingredients such as hops and barley, it is not possible for beers to gain such certificated protection for any authenticity claims based on 'ingredient branding' (Cheah et al., 2016). Thus it is not possible for beers in southern Europe to establish such a form of technical terroir (Moulard et al., 2015) through unique place-based associations as do wines where favourable associations are made between particular grape varieties and specific growing regions. However, beers may make authentic claims of place-based associations through the way brands are named and related to particular places. Because beer is relatively ubiquitous, beers may be perceived as authentic even when they are not perceived as either unique or individual (Schallehn et al, 2014). This appears to allow the concept of a terroir claim for beers wider than simple geographical links between its ingredients and its place of production, by focusing instead 
on the cultural meanings in order to differentiate various brands and allow these to gain competitive advantage through authenticity claims (Charters et al., 2017).

We acknowledge that this paper has a focus on only one industry sector, craft brewing, and on one geographical area, Corfu in Greece. However, very recently within this journal Rieple and Snijders (2018) have published research based on a single industry sector (dairy farmers) in one county (Munster) in a single country (Northern Ireland). Similarly, Thanh and Kirova (2018) focus on only one industry sector (wine production) in one region (Cognac, in France), qualitatively analysing the subjective comments placed by tourists on the online review platform TripAdvisor. However, while much more is already known about wine production in respect of tourism and the consumption of local products, to date much less is known about this in respect of craft brewing.

Therefore, although specific to the brewing industry, and although based on a single case study, we believe our findings can indeed offer practical insights into territorial brand management decisions, especially those concerning brand names that may offer clues to a product's place of origin that may offer practical strategies for SMEs operating in markets serving both local and tourist consumers. Thus this paper fills a gap in the literature identified by Charters et al. (2017) concerning the brand management of terroir products. A contribution is also made to knowledge in the areas of COO, cultural consumption and sense of place, and authenticity, particularly as this research is focused on filling two previously identified gaps in the literature on COO with regard to fast consuming goods, and low involvement products such as beer (Phau and Suntornnond, 2006), and as it relates to not only country of origin, but also region of origin (Orth et al., 2005). This study has also filled a gap in the literature concerning smaller craft breweries 
in southern Europe, which to date, have not been the focus of empirical research, possibly because this region has more historical associations with wine than with brewing and beer consumption (Nelson, 2014).

A sense of place can be suggested by companies through their territorial brand management decisions on matters concerning: Country of company ownership (place of brand origin); country / region of product production (place of product origin); and the identity of their products (brand name). Smaller regional firms may therefore be better able to better meet the needs of consumers who seek an authentic experience through their consumption of cultural products than larger global multinationals who cannot align country of brand origin with country of product or ingredient origin. Such firms tend to be in a better position to ensure that their product brand names provide an authentic sense of place, and that the place of brand origin and place of product origin also align, thus creating a holistic product identity from an inside-out perspective, that aligns with the outside-in image that consumers perceive about their products.

\section{References}

Argent, N. (2017). Heading down to the local? Australian rural development and the evolving spatiality of the craft beer sector. Journal of Rural Studies (in press) doi.org/10.1016/j.jrurstud.2017.01.016

Bech-Larsen, T., Esbjerg, L., Grunert, K.G., Juhl, H.J., \& Brunsø, K. (2007). The Supermalt identity: how Brixton-based Afro-Caribbean consumers construct a Danish malt beer brand as one of their own. Journal of Product \& Brand Management, 16, 5-15. 
Buchanan, D.A. (1999). The Logic of Political Action: an Experiment with the Epistemology of the Particular. British Journal of Management, 10, S73-S88.

Burghausen, M. \& Balmer, J.M.T. (2014). Corporate heritage identity management and the multi-modal implementation of a corporate heritage identity. Journal of Business Research, 67, 2311-2323.

Calori, R., Johnson, G., \& Sarnin, P. (1992). French and British Top Managers' Understanding of the Structure and the Dynamics of their Industries: A Cognitive Analysis and Comparison. British Journal of Management, 3, 61-78.

Carroll, G., \& Wheaton, D. (2009). The organizational construction of authenticity: An examination of contemporary food and dining in the U.S. Research in Organizational Behavior, 29, 255-282.

Charters, S., Spielmann, N., \& Babin, B.J. (2017). The nature and value of terroir products. European Journal of Marketing, 51, 748-771.

Cheah, I., Zainol, Z., \& Phau, I. (2016). Conceptualizing country-of-ingredient authenticity of luxury brands. Journal of Business Research, 69, 5819-5826.

Eades D., Arbogast D., \& Kozlowski J. (2017). Life on the ‘Beer Frontier’: A Case Study of Craft Beer and Tourism in West Virginia. In: Kline C., Slocum S., \& Cavaliere C. (eds) Craft Beverages and Tourism, Volume 1. Cham: Palgrave Macmillan. 
Eberts D. (2014). Neolocalism and the Branding and Marketing of Place by Canadian Microbreweries. In: Patterson M., \& Hoalst-Pullen N. (eds) The Geography of Beer. Dordrecht: Springer.

Eroglu, S., \& Machleit, K.A. (1989). Effects of individual and product-specific variables on utilising country of origin as a product quality cue. International Marketing Review, 6, 2741.

European Commission (2016) [Internet] http://ec.europa.eu/agriculture/quality/schemes/index_en.htm [Accessed 20th October 2016]

European Commission (2017) [Internet] http://ec.europa.eu/agriculture/quality/door/list.html [Accessed 23rd March 2017]

Flack, W. (1997). American microbreweries and neolocalism: 'Ale-ing' for a sense of place. Journal of Cultural Geography, 16, 37-53.

Gatrell, J., Reid, N., \& Steiger, T.L. (2018). Branding spaces: Place, region, sustainability and the American craft beer industry. Applied Geography, 90, 360-370. 
Geppert, M., Dörrenbächer, C. Gammelgaard. J, \& Taplin, I. (2013). Managerial Risk-taking in International Acquisitions in the Brewery Industry: Institutional and Ownership Influences Compared. British Journal of Management, 24, 316-332.

Godey, B., Pederzoli, D., Aiello, G., Donvito, R., Chan, P., Oh, H., Singh, R., Skorobogatykh, I.I., Tsuchiya, J., \& Weitz, B. (2012). Brand and country-of-origin effect on consumers’ decision to purchase luxury products. Journal of Business Research, 65, 1461-1470.

Greaves, N., \& Skinner, H., (2010). The importance of destination image analysis to UK rural tourism. Marketing Intelligence and Planning, 28, 486-507.

Han, C.M. (1989). Country image: Halo or summary construct? Journal of Marketing Research, 26, 222-229.

Harris, L.C., \& Ogbonna, E. (2007). Ownership and Control in Closely-held Family-owned Firms: An Exploration of Strategic and Operational Control. British Journal of Management, 18, 5-26.

Hautz, J., Mayer, M.C.J., \& Stadler, C. (2013). Ownership Identity and Concentration: A Study of their Joint Impact on Corporate Diversification. British Journal of Management, 24, 102-126. 
Hede, A-M., \& Watne, T. (2013). Leveraging the human side of the brand using a sense of place: Case studies of craft breweries. Journal of Marketing Management, 29, 207-224.

Hopkins, M. (1977). Corfu. London: B T Batsford Ltd.

Howard, P.H. (2014). Too big to ale? Globalization and consolidation in the beer industry. In: Patterson M., \& Hoalst-Pullen N. (eds) The Geography of Beer. Dordrecht: Springer.

Hurst, J.L., \& Niehm, L.S. (2012). Tourism shopping in rural markets: a case study in rural Iowa. International Journal of Culture, Tourism and Hospitality Research, 6, 194-208.

Johansson, J., Douglas, S.P., \& Nonaka, I. (1985). Assessing the impact of country of origin on product evaluations: A new methodological perspective. Journal of Marketing Research, $22,388-396$.

Josias, A.E., Frikkie, H., \& Johan, B. (2014). Region-of-origin (ROO) certification as marketing strategy in the South African wine market. International Journal of Wine Business Research, 26, 139-162.

Kalandides, A. (2011). The problem with spatial identity: revisiting the 'sense of place'. Journal of Place Management and Development, 4, 28-39.

Kotler, P., \& Gertner, D. (2002). Country as brand, product, and beyond: A place marketing and brand management perspective. Journal of Brand Management, 9, 249-261. 
Lee, J.K., Lee, B-K., \& Lee, W-N. (2013). Country-of-origin fit's effect on consumer product evaluation in cross-border strategic brand alliance. Journal of Business Research, 66, 354363.

Lewis, C., \& Stubbs, S. (1999). National expansion of British regional brands: parallels with internationalisation. Journal of Product \& Brand Management, 8, 369-386.

Melewar, T.C., \& Karaosmanoglu, E. (2006). Seven dimensions of corporate identity: A categorisation from the practitioners' perspectives. European Journal of Marketing, 40, 846-869.

Moulard, J., Babin, B.J., \& Griffin, M. (2015). How aspects of a wine's place affect consumers' authenticity perceptions and purchase intentions: The role of country of origin and technical terroir. International Journal of Wine Business Research, 27, 61-78.

Nelson, M. (2014). The geography of beer in Europe from 1000 BC to AD 1000. In: Patterson M., \& Hoalst-Pullen N. (eds) The Geography of Beer. Dordrecht: Springer.

Newey, L.R., \& Zahra, S.A. (2009). The Evolving Firm: How Dynamic and Operating Capabilities Interact to Enable Entrepreneurship. British Journal of Management, 20, S81S100. 
O'Connor, T.S. (2014). Trade dress: The increasing importance of an ancient yet new form of intellectual property protection. Journal of Business Research, 67, 303-306.

O’Neill, C., Houtman, D., \& Aupers, S. (2014). Advertising real beer: Authenticity claims beyond truth and falsity. European Journal of Cultural Studies, 17, 585-601.

Onwuegbuzie, A.J., \& Collins, K.M.T. (2007). A Typology of Mixed Methods Sampling Designs in Social Science Research. The Qualitative Report, 12, 281-316.

Orth, U.R., McGarry Wolf, M., \& Dodd, T.H. (2005). Dimensions of wine region equity and their impact on consumer preferences. Journal of Product \& Brand Management, 14, 8897.

Patterson, M., \& Hoalst-Pullen, N. (2014). Geographies of Beer. In: Patterson M., \& HoalstPullen N. (eds) The Geography of Beer. Dordrecht: Springer.

Phau, I., \& Suntornnond, V. (2006). Dimensions of consumer knowledge and its impacts on country of origin effects among Australian consumers: a case of fast-consuming product. Journal of Consumer Marketing, 23, 34-42.

Pitta, D.A., \& Scherr, B.G. (2009). The product strategy for seasonal products. Journal of Product \& Brand Management, 18, 152-153. 
Rajagopal, \& Sanchez, R. (2004). Conceptual analysis of brand architecture and relationships within product categories. Journal of Brand Management, 11, 233-247.

Rieple, A., \& Snijders, S. (2018). The role of emotions in the choice to adopt, or resist, innovations by Irish dairy farmers. Journal of Business Research, 85, 23-31.

Schallehn. M., Burmann, C., \& Riley, N. (2014). Brand authenticity: model development and empirical testing. Journal of Product \& Brand Management, 23,192-199.

Schnell, S.M., \& Reese, J.F. (2014). Microbreweries, place and identity in the United States. In: Patterson M., \& Hoalst-Pullen N. (eds) The Geography of Beer. Dordrecht: Springer.

Schnell, S.M., \& Reese, J.F. (2003). Microbreweries as tools of local identity. Journal of Cultural Geography, 21, 45-69.

Simms, J. (2008). When Brands Fake their Nationality. Campaign US, 4 March, 2008, [Internet] http://www.campaignlive.com/article/when-brands-fake-nationality/787693 [Accessed 20th October 2016]

Skinner, H. (2015). Sun, Sea, Sand and Sex: Problems with the mass tourism model. Proceedings of the $2^{\text {nd }}$ Corfu Symposium on Managing \& Marketing Places, Corfu, 27-30 April 2015 
Suter, M.B., Borini, F.M., Floriani, D.E., da Silva, D., \& Polo, E. (2018). Country-of-origin image (COI) as a country-specific advantage (CSA): Scale development and validation of COI as a resource within the firm perspective. Journal of Business Research, 84, 45-58.

Thakor, M.V., \& Lavack, A.M. (2003). Effect of perceived brand origin associations on consumer perceptions of quality. Journal of Product \& Brand Management, 12, 394-407.

Thanh, T.V., \& Kirova, V. (2018). Wine tourism experience: A netnography study. Journal of Business Research, 83, 30-37.

Tse, D., \& Gorn, G.J. (1993). An experiment on the salience of Country-of-Origin in the era of global brands. Journal of International Marketing, 1, 57-76.

Vrellas, C. G., \& Tsiotras, G. D. (2014). Operational Excellence in the Greek Brewing Industry. Global Business and Organisational Excellence, 33, 31-38.

Williams, H.A., Williams, R.L.Jr., \& Omar, M. (2014). Gastro-tourism as destination branding in emerging markets. International Journal of Leisure and Tourism Marketing, 4, 1-18.

World Health Organisation (2014) Global Status report on alcohol and health 2014, available at: http://www.who.int/substance_abuse/publications/global_alcohol_report/msb_gsr_2014_1. pdf?ua=1 (accessed 13 November 2014). 
Yool, S., \& Comrie, A. (2014). A taste of place: Environmental geographies of the classic beer styles. In: Patterson M., \& Hoalst-Pullen N. (eds) The Geography of Beer. Dordrecht: Springer.

Zhou, L., Yang, Z. and Hui, M.K. (2010). Non-local or local brands? A multi-level investigation into confidence in brand origin identification and its strategic implications. Journal of the Academy of Marketing Science, 38, 202-218.

Table 1: Beer brand preferences

\begin{tabular}{|l|r|r|r|r|r|}
\hline \multicolumn{9}{|c}{$\begin{array}{c}\text { Extremely } \\
\text { low }\end{array}$} & \multicolumn{1}{|c|}{$\begin{array}{c}\text { Extremely } \\
\text { high }\end{array}$} \\
\hline & 1 & 2 & 3 & 4 & 5 \\
\hline Mythos & $4.74 \%$ & $6.84 \%$ & $18.95 \%$ & $31.05 \%$ & $38.42 \%$ \\
\hline Alfa & $12.92 \%$ & $17.98 \%$ & $32.58 \%$ & $25.28 \%$ & $11.24 \%$ \\
\hline Corfu Beer & $5.46 \%$ & $7.10 \%$ & $21.31 \%$ & $21.31 \%$ & $44.81 \%$ \\
\hline
\end{tabular}


Table 2: Perceptions of authenticity

\begin{tabular}{|c|c|c|c|c|c|}
\hline & $\begin{array}{c}\text { Least } \\
\text { authentically } \\
\text { Greek }\end{array}$ & & & & $\begin{array}{c}\text { Most } \\
\text { authentically } \\
\text { Greek }\end{array}$ \\
\hline & 1 & 2 & 3 & 4 & 5 \\
\hline Mythos & $5.3 \%$ & $9.27 \%$ & $22.52 \%$ & $27.15 \%$ & $35.76 \%$ \\
\hline Alfa & $11.49 \%$ & $19.59 \%$ & $32.43 \%$ & $28.38 \%$ & $8.11 \%$ \\
\hline Corfu Beer & $4.82 \%$ & $3.01 \%$ & $15.66 \%$ & $27.71 \%$ & $48.80 \%$ \\
\hline
\end{tabular}


Table 3: Beer preference, brand names and local consumption

\begin{tabular}{|c|c|c|c|c|c|c|}
\hline \multirow{3}{*}{$\begin{array}{l}\text { When you are in } \\
\text { Corfu how important } \\
\text { is it for you to } \\
\text { consume local food } \\
\text { and drink? }\end{array}$} & \multicolumn{2}{|c|}{$\begin{array}{l}\text { Mythos } \\
(n=131)\end{array}$} & \multicolumn{2}{|c|}{$\begin{array}{c}\text { Alfa } \\
(n=65)\end{array}$} & \multicolumn{2}{|c|}{$\begin{array}{c}\text { Corfu Beer } \\
(n=120)\end{array}$} \\
\hline & $\begin{array}{l}\text { Extremely or } \\
\text { of some } \\
\text { importance }\end{array}$ & $\begin{array}{l}\text { Little or no } \\
\text { importance }\end{array}$ & $\begin{array}{l}\text { Extremely } \\
\text { or of some } \\
\text { importance }\end{array}$ & $\begin{array}{l}\text { Little or no } \\
\text { importance }\end{array}$ & $\begin{array}{l}\text { Extremely } \\
\text { or of some } \\
\text { importance }\end{array}$ & $\begin{array}{l}\text { Little or no } \\
\text { importance }\end{array}$ \\
\hline & $\begin{array}{l}98.5 \% \\
\mathrm{n}=129\end{array}$ & $\begin{array}{r}1.5 \% \\
\mathrm{n}=2\end{array}$ & $\begin{array}{r}98.5 \% \\
\mathrm{n}=64\end{array}$ & $\begin{array}{r}1.5 \% \\
\mathrm{n}=1\end{array}$ & $\begin{array}{l}99.2 \% \\
n=119\end{array}$ & $\begin{array}{r}0.8 \% \\
\mathrm{n}=1\end{array}$ \\
\hline \multirow{2}{*}{$\begin{array}{l}\text { A beer's brand name } \\
\text { helps me know which } \\
\text { country it is from }\end{array}$} & Yes & No & Yes & No & Yes & No \\
\hline & $\begin{array}{r}72 \% \\
\mathrm{n}=94 \\
\end{array}$ & $\begin{array}{r}28 \% \\
\mathrm{n}=37 \\
\end{array}$ & $\begin{array}{r}75 \% \\
\mathrm{n}=49 \\
\end{array}$ & $\begin{array}{r}25 \% \\
\mathrm{n}=16 \\
\end{array}$ & $\begin{array}{r}73.3 \% \\
\mathrm{n}=88 \\
\end{array}$ & $\begin{array}{r}26.7 \mid \% \\
\mathrm{n}=32 \\
\end{array}$ \\
\hline \multirow{2}{*}{$\begin{array}{l}\text { If a beer is brewed by } \\
\text { a Greek company, } \\
\text { does it matter to you } \\
\text { if that company is } \\
\text { owned by a global } \\
\text { company such as } \\
\text { Heineken or } \\
\text { Carlsberg? }\end{array}$} & Yes & No & Yes & No & Yes & No \\
\hline & $\begin{array}{r}44.3 \% \\
\mathrm{n}=58\end{array}$ & $\begin{array}{r}55.7 \% \\
\mathrm{n}=73\end{array}$ & $\begin{array}{r}50.7 \% \\
\mathrm{n}=33\end{array}$ & $\begin{array}{r}49.3 \% \\
n=32\end{array}$ & $\begin{array}{r}58.3 \% \\
\mathrm{n}=70\end{array}$ & $\begin{array}{r}41.7 \% \\
\mathrm{n}=50\end{array}$ \\
\hline
\end{tabular}




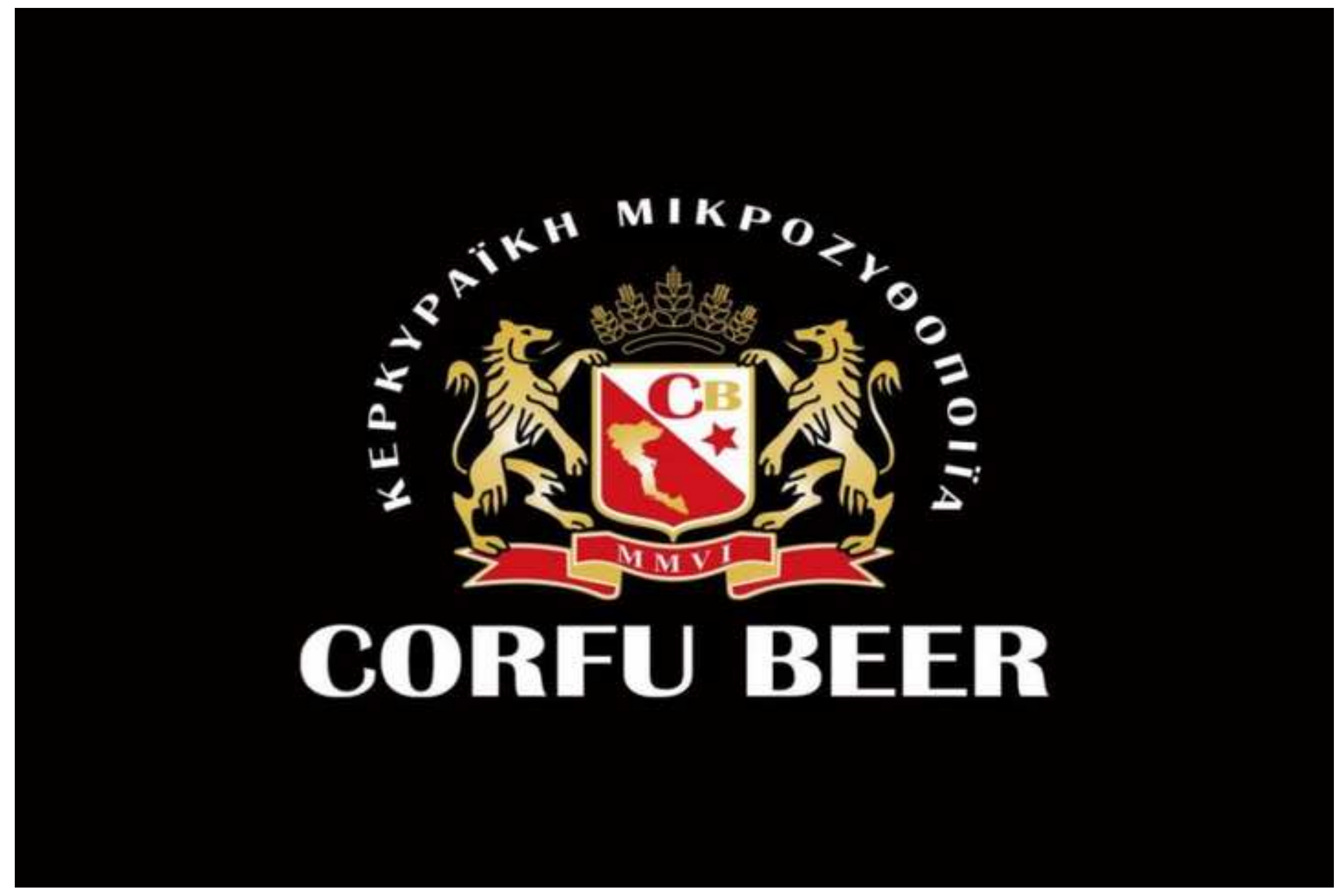

Clck here to download high resolution image

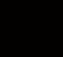

